\title{
QUANTITATIVE ASPECTS OF TRITERPENE SYNTHESIS IN THE LATICIFERS OF HOYA DIVERSIFOLIA BL.
}

\author{
HENRI W. GROENEVELD and BART VAN DER BURG
}

Botanisch Laboratorium, Rijksuniversiteit, Lange Nieuwstraat 106, 3512 PN Utrecht (The Netherlands)

(Received May 25th, 1983)

(Revision received August 1st, 1983)

(Accepted August 1st, 1983)

\section{SUMMARY}

The esterified triterpenes extracted from the stem of Hoya diversifolia were found to represent the latex triterpenes. The triterpene content of the five apical internodes was fairly constant, ranging from $0.4-0.5 \mathrm{mg}$ $\mathrm{cm}^{-1}$ stem in growing plants and values of $0.52-0.60 \mathrm{mg} \mathrm{cm}{ }^{-1}$ were obtained from slowly or non-growing plants. When $\left[{ }^{14} \mathrm{C}\right]$ sugars were absorbed by node-containing stem segments, a $\left[{ }^{14} \mathrm{C}\right]$ latex triterpene synthesis could be observed for several weeks. After 4 weeks up to $9 \%$ of the supplied $\left[{ }^{14} \mathrm{C}\right]$ sugars had been involved in latex lipid metabolism. In this period the stem segments had synthesized the amount of the latex lipids which was lost at excision (about $50 \%$ ). No remarkable quantitative differences in latex triterpene synthesis were observed in the five apical internodes.

Key words: Laticifers - Triterpene synthesis - Hoya diversifolia $\mathrm{Bl}$.

\section{INTRODUCTION}

The leafless whips of $H$. diversifolia, Asclepiadaceae consisting of 5-7 internodes with a diameter of $3-6 \mathrm{~mm}$, are characterized by an abundance of latex. Triterpenyl cinnamates are the major constituents of the latex particles of this plant [1]. These triterpene esters and the free triterpenols of the latex particles are exclusively synthesised in the wall-lining cytoplasm of the laticifers [2-4]. When sugars were absorbed by excised stem segments, mainly $\left[{ }^{14} \mathrm{C}\right]$ latex triterpenes and their esters were synthesised, as far as the apolar lipids are concerned. Little ${ }^{14} \mathrm{C}$ was traced in the caro-

Abbreviations: GLC, gas liquid chromatography; TLC, thin-layer chromatography. 
tenoids and phytosterols of non-latex origin [4]. Under these experimental conditions stem segments with a length of at least $10 \mathrm{~cm}$ gave a reproducible $\left[{ }^{14} \mathrm{C}\right]$ triterpene yield (Groeneveld, unpublished results). The maximum incubation time in these experiments was $48 \mathrm{~h}$ and they were not conclusive about the total capacity and rate of latex synthesis. Compared with the used segments of internodes, stem segments with a node and two auxillary buds have a prolonged life and can be rooted within 7 weeks. As such node-containing stem segments can be tapped at regular intervals, the latex production over longer periods can be assayed. Results of such longterm experiments on latex production and triterpene yield in non-articulated laticifers are presented in this paper, which is the first quantitative report on latex production and yield in the non-articulated laticifers of $H$. diversifolia.

\section{MATERIALS AND METHODS}

Plants of $H$. diversifolia $\mathrm{Bl}$. (obtained from the coastal vegetation of Meru Betiri, South East Jawa, Indonesia) were grown on hydroculture in the greenhouse. Segments from the leafless whips were used in the incorporation experiments.

\section{Lipid extraction}

Latex, obtained after incision, was diluted 5-fold with a $0.2 \mathrm{M} \mathrm{K}_{2} \mathrm{HPO}_{4}$ solution, mixed with an equal part of acetone and extracted with light petroleum $(40-60)$ [4]. Stem tissue was sliced into 2-3-mm segments and extracted with acetone in a soxhlet apparatus for $2 \mathrm{~h}$. The acetone extract was evaporated to dryness and the light petroleum extract was prepared as described by Grunwald [5]. The apolar lipids in the light petroleum extract were separated by adsorption chromatography on alumina [6]. With a stepwise increase of di-ethyl ether in light petroleum three fractions were obtained: the triterpene and sterol esters, the free titerpenols (4,4-dimethyl sterols) and the sterol (4-desmethyl sterol) containing fraction. The triterpene and sterol moiety were liberated from their corresponding esters by saponification in $5 \% \mathrm{KOH}$ in methanol/benzene $(19: 1$, $\mathrm{v} / \mathrm{v}$ ) for $2 \mathrm{~h}$ at $95^{\circ} \mathrm{C}$, extracted with light petroleum and subsequently isolated by alumina adsorption chromatography. Aliquots of all the obtained fractions were checked by thin-layer chromatography (TLC) on silicagel (developed in cyclohexane/ethylacetate, $5: 1, \mathrm{v} / \mathrm{v}$ ) modified after [7].

\section{Gas liquid chromatography (GLC)}

The saponified esters, triterpenols and sterols or the saponified light petroleum extract were separated on a $3 \% \mathrm{SE}-30$ column at $250^{\circ} \mathrm{C}$ with an appropriate amount of $5 \alpha$-cholestane as internal standard for quantitative lipid assay. 
Incorporation experiments

$\left[\mathrm{U} \cdot{ }^{14} \mathrm{C}\right]$ glucose, $\left[\mathrm{U} \cdot{ }^{14} \mathrm{C}\right]$ sucrose solutions $(100-150 \mu \mathrm{l})$ were absorbed by excised stem segments $(12-15 \mathrm{~cm})$. These stem parts were subsequently transferred to moist vermiculite and incubated in the green house at 20$25^{\circ} \mathrm{C}$. Latex was tapped at regular intervals (by cutting a 2-mm slice frcm the basal part of the incubated stem segment) and diluted with $0.2 \mathrm{M}$ $\mathrm{K}_{2} \mathrm{HPO}_{4}$.

Aliquots of the stable suspension were mixed with lumagel and counted in a liquid scintillation counter. The labelled esters, free triterpenols and sterol-containing fractions (obtained in alumina adsorption chromatography) were separated by GLC. The ${ }^{14} \mathrm{C}$-spots, traced with a radiochromatogram scanner, were scraped off and the ${ }^{14} \mathrm{C}$-content determined in a liquid scintillation counter. The total ${ }^{14} \mathrm{C}$-content of tissue was assayed by extracting $2-\mathrm{mm}$ stem slices with ethanol $80 \%$ at $50^{\circ} \mathrm{C}$ for $16 \mathrm{~h}$. The residue was dried and combusted in a Packard sample oxydiser. The ${ }^{14} \mathrm{C}$ of both fractions was measured in a liquid scintillation counter.

\section{RESULTS}

Results of a quantitative GLC-analysis of the esterified and free triterpenes in latex and stem of $H$. diversifolia are presented in Table I. All the fractions investigated showed similar retention times to $5 \alpha$-cholestane. The close resemblance between the esterified triterpenes from stem and latex indicates that the lipids of both fractions had the same origin. As the latex is not completely expelled from the stem segments after excision the remaining latex lipids account for a considerable part in the apolar lipids of this tissue. Apparently the amount of esterified triterpenes from cells other than laticifers is too low to alter significantly the composition of the latex. This means that the esterified triterpenes extracted from the stem represent

\section{TABLE I}

GLC-DISTRIBUTION OF TRITERPENES FROM STEM AND LATEX OF $H$. DIVERSIFOLIA

In all the fractions measured the amounts of triterpenes with $R_{f} 2.98$ and 4.08 were related to those measured at $R_{f}, 3.30$.

\begin{tabular}{|c|c|c|c|c|}
\hline \multirow[t]{2}{*}{$R_{f}$ to $5 \alpha$-cholestane } & & \multicolumn{3}{|c|}{ Relative amount of triterpenes } \\
\hline & & $(2.98)$ & $(3.30)$ & $(4.08)$ \\
\hline $\begin{array}{l}\text { Triterpene-moiety of } \\
\text { esterified triterpenes }\end{array}$ & $\left\{\begin{array}{l}\text { Latex } \\
\text { Stem }\end{array}\right.$ & $\begin{array}{l}0.72 \\
0.72\end{array}$ & $\begin{array}{l}1.00 \\
1.00\end{array}$ & - \\
\hline Free triterpenes & $\left\{\begin{array}{l}\text { Latex } \\
\text { Stem }\end{array}\right.$ & $\begin{array}{l}1.02 \\
2.58\end{array}$ & $\begin{array}{l}1.00 \\
1.00\end{array}$ & $\begin{array}{l}0.90 \\
0.64\end{array}$ \\
\hline Unsaponifiable lipids & $\left\{\begin{array}{l}\text { Latex } \\
\text { Stem }\end{array}\right.$ & $\begin{array}{l}0.73 \\
0.83\end{array}$ & $\begin{array}{l}1.00 \\
1.00\end{array}$ & $\begin{array}{l}0.06 \\
0.07\end{array}$ \\
\hline
\end{tabular}


the esterified triterpenes of the latex and can be used as a reference for latex lipids.

GLC of the free triterpenes (triterpenols or 4,4-dimethylsterols) revealed similar retention times to $5 \alpha$-cholestane but a different mass distribution. The free triterpenes account only for 8-9\% of the total triterpene content of the latex, 91-92\% occurs as triterpenylcinnamates. Due to the abundance of these esters in the latex the non-saponifiable lipids from stem and latex show a close resemblance in GLC. From these figures may be concluded that at least $94 \%$ of the non-saponifiable lipids from the stem of $H$. diversifolia accounts for latex lipids and even this fraction may be used to assay the latex lipid content of stem tissue of this plant.

\section{Triterpene distribution in the stem}

The triterpene content of various parts of several whips is presented in Fig. 1. In rapidly growing stems (normally used in the incorporation experiments) an amount of $0.40-0.48 \mathrm{mg}$ latex triterpene $\cdot \mathrm{cm}^{-1}$ was measured in the 6 apical internodes. In these internodes secondary thickening gradually occurs, causing a decrease in triterpene content per gram fresh weight. The constant value of the triterpene amount per $\mathrm{cm}$ stem supports the view that secondary thickening is not characterised by a significant increase in the number of latex vessels. This agrees with the anatomy of the laticiferous system.

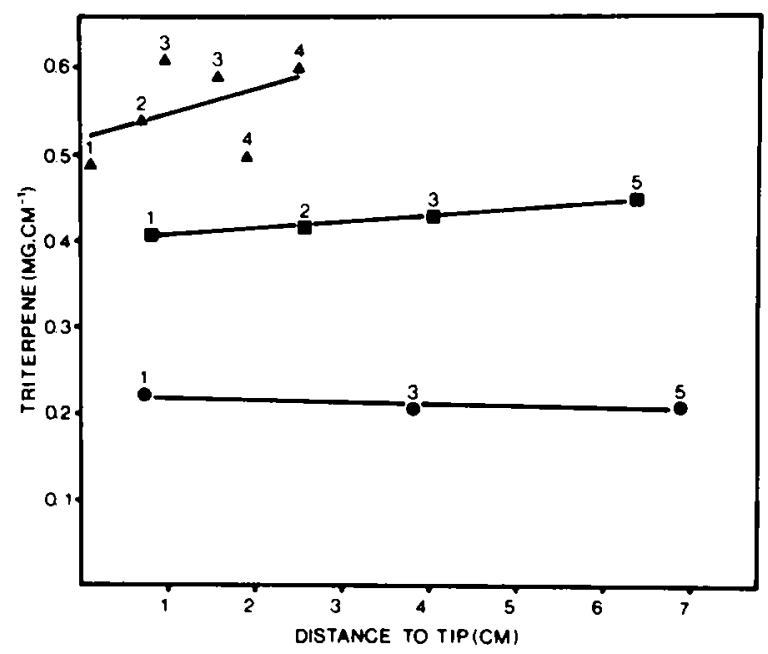

Fig. 1. Latex triterpene distribution $\left(\mathrm{mg} \cdot \mathrm{cm}^{-1}\right)$ in various whips of $H$. diversifolia. $(\bullet)$, triterpene level in a growing whip (no latex lost at excision); $(\bullet)$, after latex loss at excision and ( 4$)$, the triterpene level in a non-growing whip. The numbers refer to the internodes from which the $4-\mathrm{cm}$ segments were excised for lipid assay. 
If the whip is not frozen before excision, up to $50 \%$ of the latex is expelled, causing a drop of the triterpene level over the whole length of the used stem part (Fig. 1).

In slowly or non-growing plants a higher level of latex lipids per $\mathrm{cm}$ stem was measured: $0.52-0.60 \mathrm{mg} \mathrm{cm}{ }^{-1}$ (Fig. 1). No attempts were made to correlate these values with the laticifer distribution in these plants. Only the rapidly growing whips $\left(0.5-0.7 \mathrm{~cm} \mathrm{day}^{-1}\right)$ were used in the incorporation experiments.

\section{Incorporation experiments}

To determine a substrate consumption in latex triterpene synthesis stem segments of $14-\mathrm{cm}$ length were excised from the second and fourth internode and they absorbed $\left[\mathrm{U}-{ }^{14} \mathrm{C}\right]$ glucose $\left(462 \mathrm{kBq}, 114.7 \mathrm{MBq} \mathrm{mmol}^{-1}\right)$. The latex was tapped after $48 \mathrm{~h}$ and results presented in Table II show that $20-25 \%$ of the $\left[{ }^{14} \mathrm{C}\right]$ triterpenes was measured in the tapped latex. Radioactive carbon from $\left[\mathrm{U}-{ }^{14} \mathrm{C}\right]$ glucose is exclusively incorporated into the latex triterpenes [1]. The 4-desmethylsterols, occurring in the latex as traces only, are synthesised in the incubated tissue. Labelled triterpenol intermediates of this sterol synthesis (e.g. cycloartenol, 24- $\mathrm{CH}_{2}$-cycloartanol) were not traced if $\left[{ }^{14} \mathrm{C}\right]$ sugars were used as a substrate. Therefore all the $\left[{ }^{14} \mathrm{C}\right]$ triterpenes extracted from the stem are supposed to be synthesised in the laticifers.

The glucose used in this lipid synthesis is catabolised via the glycolysis and acetyl-CoA is subsequently used as a substrate in squalene synthesis. This pathway has a concurrent production of 24 molecules of $\mathrm{CO}_{2}$ per molecule of triterpenol $[8,9]$. If $\left[\mathrm{U}^{-14} \mathrm{C}\right]$ glucose is used, the ${ }^{14} \mathrm{C}$ assayed in the triterpenes $\left(\mathrm{C}_{30}\right)$ represents $30 / 54$ part of the label of glucose used in this synthesis. Therefore $5706 \mathrm{~Bq}$ obtained in all the triterpenes of the

\section{TABLE II}

INCORPORATION OF ${ }^{14} \mathrm{C}$ FROM [U ${ }^{14} \mathrm{C}$ ]GLUCOSE (462 kBq, $114.7 \mathrm{MBq} \mathrm{mMOL}^{-1}$ ) INTO ESTERIFIED TRITERPENES, FREE TRITERPENOLS AND STEROLS BY $14-\mathrm{cm}$ STEM SEGMENTS OF THE 2nd AND 4th INTERNODE OF H. DIVERSIFOLIA

After $48 \mathrm{~h}$ of incubation the latex was tapped and the amount of ${ }^{14} \mathrm{C}$-lipids in the latex and the remaining stem tissue was determined.

\begin{tabular}{llllll}
\hline & \multicolumn{2}{l}{ Internode 2 } & & \multicolumn{2}{l}{ Internode 4 } \\
\cline { 2 - 3 } \cline { 5 - 6 } & Latex & Stem & & Latex & Stem \\
& dps & dps & & dps & dps \\
\hline Lipid extract & 2808 & 7913 & & 1991 & 8137 \\
Esterified triterpenes & 1225 & 3377 & & 873 & 2775 \\
Free triterpenols & 285 & 819 & & 208 & 901 \\
Free sterols & 35 & 238 & & 20 & 467 \\
\hline
\end{tabular}


segment of internode 2 represents $10270 \mathrm{~Bq}\left[{ }^{14} \mathrm{C}\right]$ glucose, being $2.2 \%$ of the supplied substrate. A figure of $1.9 \%$ was calculated for the segment of internode 4.

Most of the $\left[{ }^{14} \mathrm{C}\right]$ sugar incubated $14-\mathrm{cm}$ stem segments could be tapped twice a week for about 30 days. The soft apical stem part consisting of the first two internodes produced latex for 16-18 days only. All the radioactivity in the tapped latex (incorporated in the triterpenes as well as in the water soluble serum constituents) obtained at regular tapping intervals for the first 4 weeks is presented in Fig. 2. The highest yield of ${ }^{14} \mathrm{C}$-secretion was measured for the first 10 days of the experiment. In general a decrease in ${ }^{14} \mathrm{C}$-content of the tapped latex and in its triterpenes was observed from the 14th day onwards. After 28 days no latex was expelled at incision of the incubated stem segments. In that period $2916 \mathrm{~Bq}{ }^{14} \mathrm{C}$ was obtained in the latex triterpenes, representing $27 \%$ of the total ${ }^{14} \mathrm{C}$-content of the latex. The petroleum ether soluble constituents accounted for $55 \%$ of the total radioactivity (Fig. 3). These mutual ratios were measured after 28 days of incorporation and a time course experiment revealed that these ratios were obtained from the 4 th day onwards (Fig. 4). During the first day of

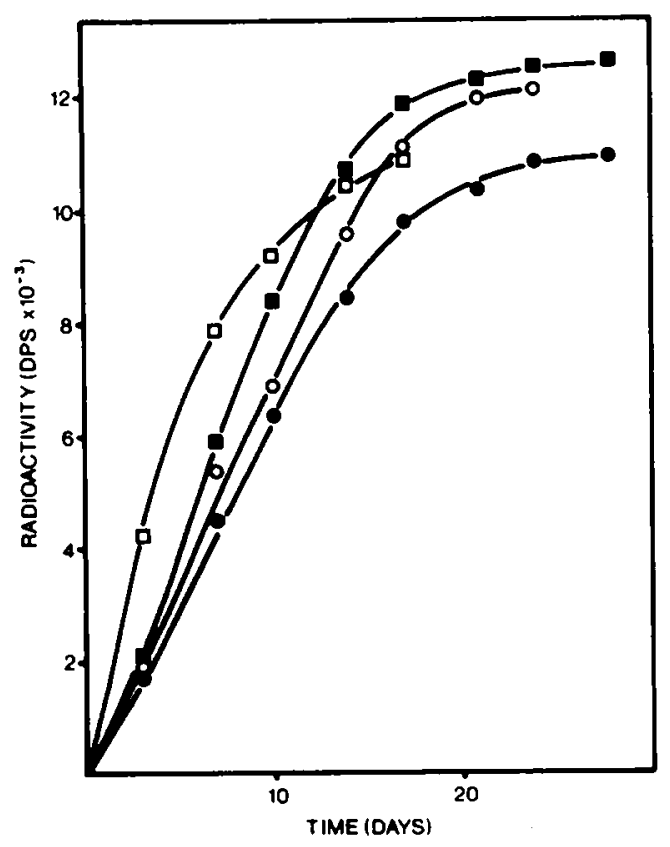

Fig. 2. Cumulative representation of ${ }^{14} \mathrm{C}$ recovery in the tapped latex of excised $14 \cdot \mathrm{cm}$ stem segments vs. time. The segments were obtained from various internodes of a single plant and absorbed each $185 \mathrm{kBq}\left[\mathrm{U}^{14}{ }^{14}\right.$ ] glucose, spec. act. $114.7 \mathrm{MBq} \mathrm{mmol}^{-1} .(0)$, Segment from the first and second internode; $(\bullet)$, third internode; $(c)$, fourth internode; $(\bullet)$, fifth internode. 


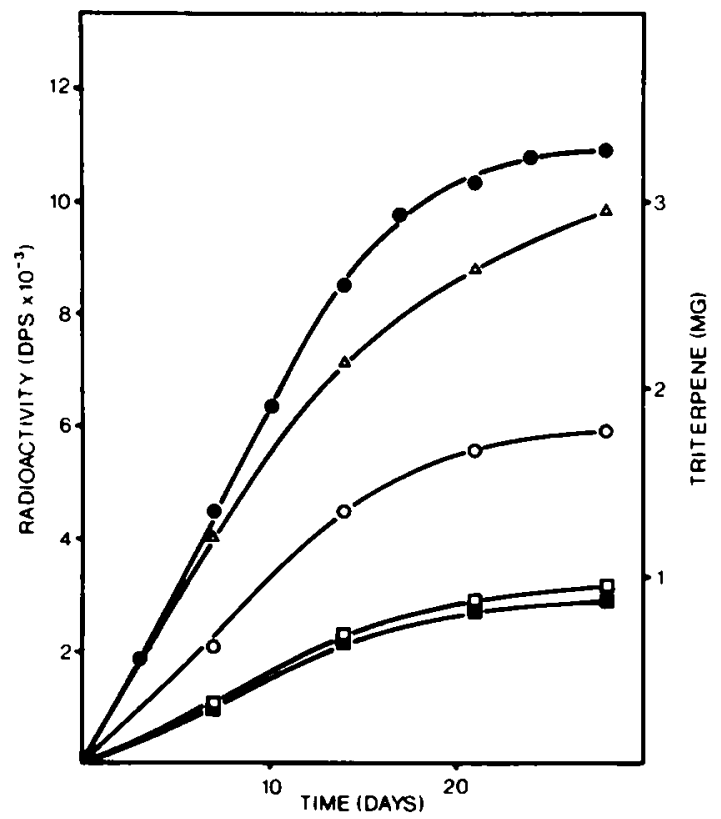

Fig. 3. Cumulative representation of the triterpene yield $(\mathrm{mg}, \Delta)$ and the recovery in the various fractions of the tapped latex after absorption of $185 \mathrm{kBq}\left[\mathrm{U}^{-14} \mathrm{C}\right] \mathrm{glucose}$, (spec. act. 114.7 $\mathrm{MBq} \mathrm{mmol}{ }^{-1}$ ) by a $14-\mathrm{cm}$ stem segment of the fifth internode. (•), Total latex; $(0)$, petroleum ether soluble fraction; $(0)$, non-saponifiable lipids and $(\bullet)$, triterpenes.

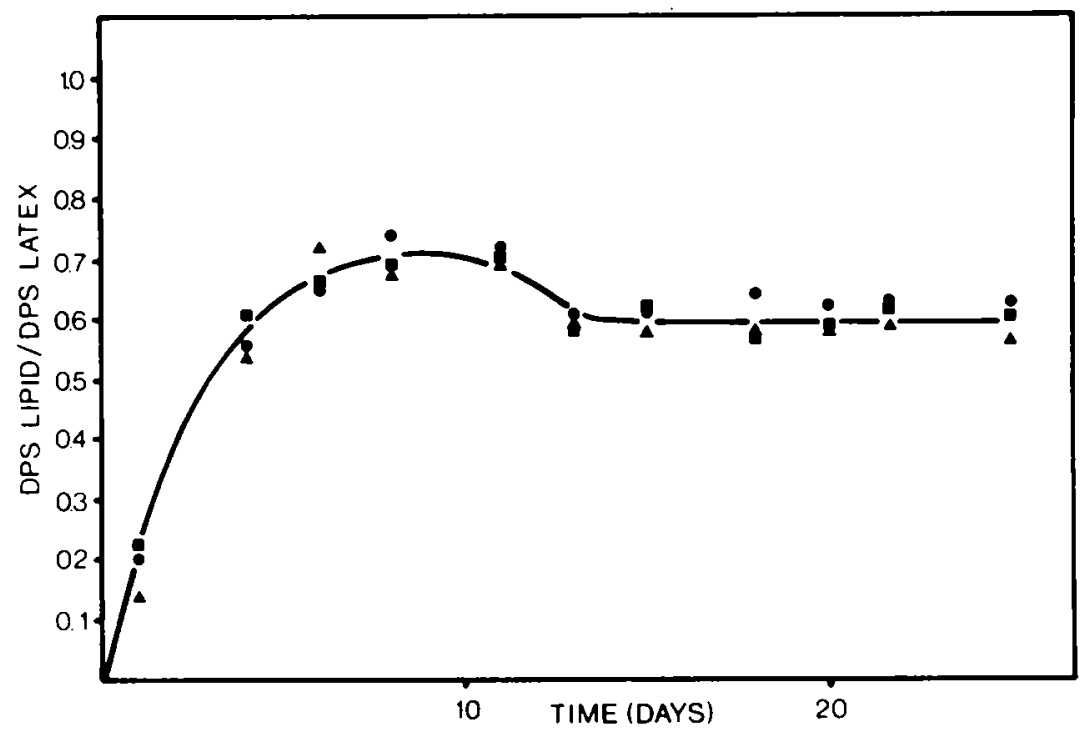

Fig. 4. The ${ }^{14} \mathrm{C}$-lipid to ${ }^{14} \mathrm{C}$-latex ratio vs. time after $\left[\mathrm{U}-{ }^{14} \mathrm{C}\right] \mathrm{glucose}$ absorption by three stem segments from various internodes, (tapped three times a week) represented by $\triangle, \oplus, \bullet\left[\mathrm{U}^{-14} \mathrm{C}\right.$ ]glucose, $114.7 \mathrm{MBq} \mathrm{mmol}^{-1} /$ segment. 
incorporation apparently non-lipid ${ }^{14} \mathrm{C}$-constituents were secreted in greater amounts than the ${ }^{14} \mathrm{C}$-lipids. After 9 days of incubation $50 \%$ of the $\left[{ }^{14} \mathrm{C}\right]$ triterpenes obtained in the tapped latex during this 28-day incubation period was already expelled with the latex (Fig. 3). After the first week of incubation a $\left[{ }^{14} \mathrm{C}\right]$ triterpene fraction with a spec. act. of $1.58 \mathrm{~Bq} / \mu \mathrm{g}$ was obtained. This value increased in the second week $(2.76 \mathrm{~Bq} / \mu \mathrm{g})$ and declined via $2.27 \mathrm{~Bq} / \mu \mathrm{g}$ towards $1.09 \mathrm{~Bq} / \mu \mathrm{g}$ in the 4 th week of incubation. The curve of the triterpene yield $(\Delta)$ in Fig. 3 suggests that after 28 days of incubation the latex triterpenes were still synthesised in the excised stem segments. As no latex was expelled after this period, the triterpene production curve could not be continued. Results in Table III, however, show that up to $65-70 \%$ of the $\left[{ }^{14} \mathrm{C}\right]$ triterpenes was present in the tapped latex. The remainder was still present in the laticifers.

These figures were not altered by a regular addition of non-labelled glucose or sucrose to the incubated stem segments, nor had the regular tappings any significant effect on the $\left[{ }^{14} \mathrm{C}\right]$ triterpene yield (Table III). The latex triterpene production capacity was equally distributed over the investigated stem segments, ranging from 2 to $3 \mathrm{mg}$ in 4 weeks. This amount equals the inevitable triterpene (latex) loss following excision of the stem segments. About $3-9 \%$ of the $\left[{ }^{14} \mathrm{C}\right]$ glucose is involved in the recovery of

\section{TABLE III}

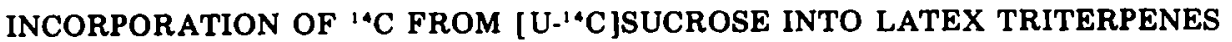

Aliquots of $185 \mathrm{kBq}\left[\mathrm{U} \cdot{ }^{14} \mathrm{C}\right.$ ]sucrose (spec. act. $115 \mathrm{MBq} \mathrm{mmol}^{-1}$ ) were absorbed by stem segments obtained from three plants $(A, B$, and $C$ ) and incubated for 28 days. Latex was tapped twice a week ( $A$ and $B$ ) and additional aliquots of $1.5 \mathrm{mg}$ sucrose were absorbed by the stem segments of plant $B$ at the end of each week. The incubated segments of plant $\mathrm{C}$ were not tapped at all. After 28 days the ${ }^{14} \mathrm{C}$-content and amount of triterpenes in both the tapped latex and the incubated tissue was assayed.

\begin{tabular}{|c|c|c|c|c|c|c|c|c|}
\hline \multirow[t]{2}{*}{ Plant } & \multirow[t]{2}{*}{ Internode } & \multirow[t]{2}{*}{$\begin{array}{l}\text { Used } \\
\text { segment } \\
\text { length } \\
\text { (cm) }\end{array}$} & \multicolumn{2}{|c|}{$\begin{array}{l}\text { Triterpene } \\
\text { amount } \\
\text { tapped }\end{array}$} & \multicolumn{2}{|c|}{$\begin{array}{l}\text { Triterpene } \\
\text { extracted } \\
\text { from the } \\
\text { stem }\end{array}$} & \multirow[t]{2}{*}{$\begin{array}{l}{\left[{ }^{14} \mathrm{C}\right]-} \\
\text { Triterpene } \\
\text { tapped } \\
(\%)\end{array}$} & \multirow{2}{*}{$\begin{array}{l}{\left[{ }^{14} \mathrm{C}\right] \text { sucrose }} \\
\text { used in } \\
\text { triterpene } \\
\text { synthesis } \\
(\%)\end{array}$} \\
\hline & & & $(\mathrm{Bq})$ & $(\mathrm{mg})$ & $(\mathrm{Bq})$ & (mg) & & \\
\hline A & 2 & 14.5 & 3558 & 2.22 & 2730 & 2.19 & 56.6 & 6.1 \\
\hline A & 3 & 14 & 3193 & 2.31 & 2501 & 2.10 & 56.1 & 5.5 \\
\hline A & 4 & 14 & 2934 & 2.98 & 1695 & 2.60 & 63.4 & 4.5 \\
\hline B & 2 & 15.5 & 5302 & 2.58 & 2377 & 1.90 & 69.1 & 7.5 \\
\hline B & 3 & 16 & 5712 & 2.72 & 3192 & 2.59 & 64.2 & 8.7 \\
\hline B & 4 & 14 & 3934 & 2.16 & 2430 & 2.29 & 61.8 & 6.2 \\
\hline C & 2 & 15 & - & - & 3272 & 4.30 & - & 3.2 \\
\hline $\mathrm{C}$ & 3 & 16 & - & - & 4735 & 5.91 & - & 4.6 \\
\hline $\mathbf{C}$ & 4 & 15 & - & - & 5438 & 7.11 & - & 5.3 \\
\hline
\end{tabular}




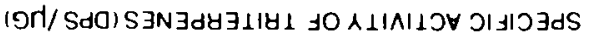

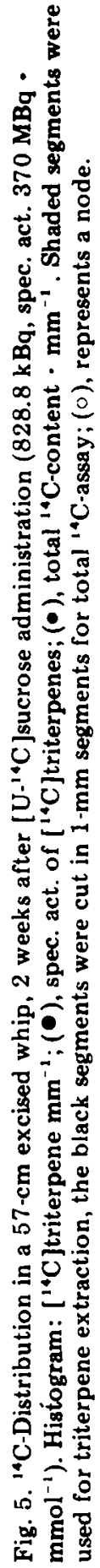


the loss of latex triterpenes. As the $\left[{ }^{14} \mathrm{C}\right]$ triterpenes represent $27 \%$ of the ${ }^{14} \mathrm{C}$ occurring in the latex $11-33 \%$ of the supplied $\left[{ }^{14} \mathrm{C}\right]$ glucose was involved in latex metabolism.

To investigate the relationship between the triterpene synthesis in the laticifers and substrate supply, apical leafless whips $(40-60 \mathrm{~cm})$ were incubated with $\left[\mathrm{U}^{14} \mathrm{C}\right]$ sucrose. After $6-15$ days the incubated stems were frozen and the 4-5-cm stem segments were excised at regular intervals to assay the triterpene and corresponding ${ }^{14} \mathrm{C}$-content. The remaining material was used to measure the total ${ }^{14} \mathrm{C}$-distribution over the stem. Results of a typical experiment are presented in Fig. 5 . The ${ }^{14} \mathrm{C}$-content $\cdot \mathrm{cm}^{-1}$ stem was the highest in the lowest part of the stem, where the $\left[{ }^{14} \mathrm{C}\right]$ sucrose was administered. The ${ }^{14} \mathrm{C}$-level decreased rapidly towards the tip. When a rapid growing tip was present, the ${ }^{14} \mathrm{C}$-level increased at this apical part. If this active tip meristeme was not present this ${ }^{14} \mathrm{C}$ increase was measured at a lower part of the stem (second or third internode). The radioactivity measured in the (latex) triterpenes extracted from various parts of the stem, was in accordance with the ${ }^{14} \mathrm{C}$ distribution over the incubated tissue. In the third and fourth internode the ${ }^{14} \mathrm{C}$-incorporation in the latex triterpenes was slightly enhanced compared with the ${ }^{14} \mathrm{C}$-level of the adjacent tissue. In this part of the stem an increased specific activity of the synthesised triterpenes was measured. Apart from the lower stem part near the ${ }^{14} \mathrm{C}$-application site, the highest specific activity of the latex triterpenes was assayed in the first internode. Apparently the contribution of endogeneous substrate in this lipid synthesis is smaller in this tissue.

In this stem a total amount of $22530 \mathrm{~Bq}\left[{ }^{14} \mathrm{C}\right]$ triterpenes was estimated by adding the $\left[{ }^{14} \mathrm{C}\right]$ triterpene extracts and interpolating the 'missing' intervals. As this figure represents $27 \%$ of the ${ }^{14} \mathrm{C}$ occurring in the latex, about $83437 \mathrm{~Bq}{ }^{14} \mathrm{C}$ is incorporated in the latex. Enhanced with $18020 \mathrm{~Bq}$ for ${ }^{14} \mathrm{CO}_{2}$ loss in triterpene synthesis a figure of $101460 \mathrm{~Bq}$ is obtained. That means that after two weeks at least $12.24 \%$ of the supplied sucrose is used in latex metabolism. In similar experiments with a 14-day incubation period up to $40 \%$ of the supplied sucrose could be used by the laticifers.

The regular tapping of the leafless $14-\mathrm{cm}$ stem segments probably prevented root formation and the auxillary buds did not sprout. The cease of latex flow after 4 weeks might be an indication that tapping was too heavy. If Hevea is tapped too heavy, a greater part of the available metabolites will be used in rubber formation and normal tissue growth is strongly hampered [10]. This process results in an autolysis of barkcells, that is known as brown bark disease. The premature death of our incubated and regularly tapped 15-cm segments suggests a similar process.

\section{REFERENCES}

1 H.W. Groeneveld, Characteristics and biosynthesis of latex particles in Hoya and Euphorbia species, Thesis, 1977, Utrecht.

2 O. Moritz and D. Frohne, Einfuehrung in die Pharmazeutische Biologie, $4^{\circ}$ Auflage, Fischer, Stuttgart, 1970, p. 206. 
3 F. Marty, C.R. Acad. Sci. (Paris), 271D (1968) 2301.

4 H.W. Groeneveld and J. Koning, Acta Bot. Neerl., 25 (3) (1976) 227.

5 C. Grunwald, Plant Physiol., 45 (1970) 663.

6 L.J. Goad and T.W. Goodwin, Biochem. J., 99 (1966) 735.

7 P. Benveniste, M.J.E. Hewlins and B.W. Fritig, Eur. J. Biochem., 9 (1969) 735.

8 H.W. Groeneveld,., Bull. Soc. Bot. Fr. 129 Actual. Bot., 1 (1982) 71.

9 H.W. Groeneveld, E.G.M. Peters, G.W. Kroese and C. Papenhuyzen, Ann. Bot., 51 (1983) 307.

10 J. Schweizer, Archief voor de Rubbercultuur, 30, (extra no.) 1 (1953) 1. 